\title{
Ferritin as a reporter gene of in vivo stem cell tracking by 9.4-T cardiac MR in a rat model of myocardial infarction
}

\author{
Eun-Ah Park, Whal Lee, Panki Kim, Hoe Suk Kim \\ From 16th Annual SCMR Scientific Sessions \\ San Francisco, CA, USA. 31 January - 3 February 2013
}

\section{Background}

The current methods utilized to track stem cells by cardiac MR are affected by important limitations, and new solutions are needed.

\section{Methods}

We tested human ferritin heavy chain (hFTH) tagged with both myc and green fluorescence protein (GFP) as a reporter gene for in vivo tracking of stem cells by cardiac MR. Rat mesenchymal stem cells (rMSCs) were transduced with lentiviurs to overexpress hFTH. Myocardia infarction was induced by cryoinjury in rats, and the animals were immediately subjected to intramyocardial injection of $100 \mu \mathrm{l}$ of $106 \mathrm{rMSCs}$ (experiment group) or buffer solution (control group) in the border zone. In vivo cine and in vivo and ex

vivo multiecho T2 weighted images were obtained by 9.4T cardiac MR.

\section{Results}

Four-week follow-up cine MR showed that marked left ventricular remodeling developed in the control group. T2 relaxation time of in vivo and ex vivo images was significantly decreased in the infarct area compared to remote normal myocardium in the experiment group, but not in the control group. GFP and myc immunestaining confirmed the presence of differentiated rMSCs around infarct area in the experiment group.

\section{Conclusions}

hFTH can be used as a MR reporter gene to track dividing and differentiating stem cells in the beating

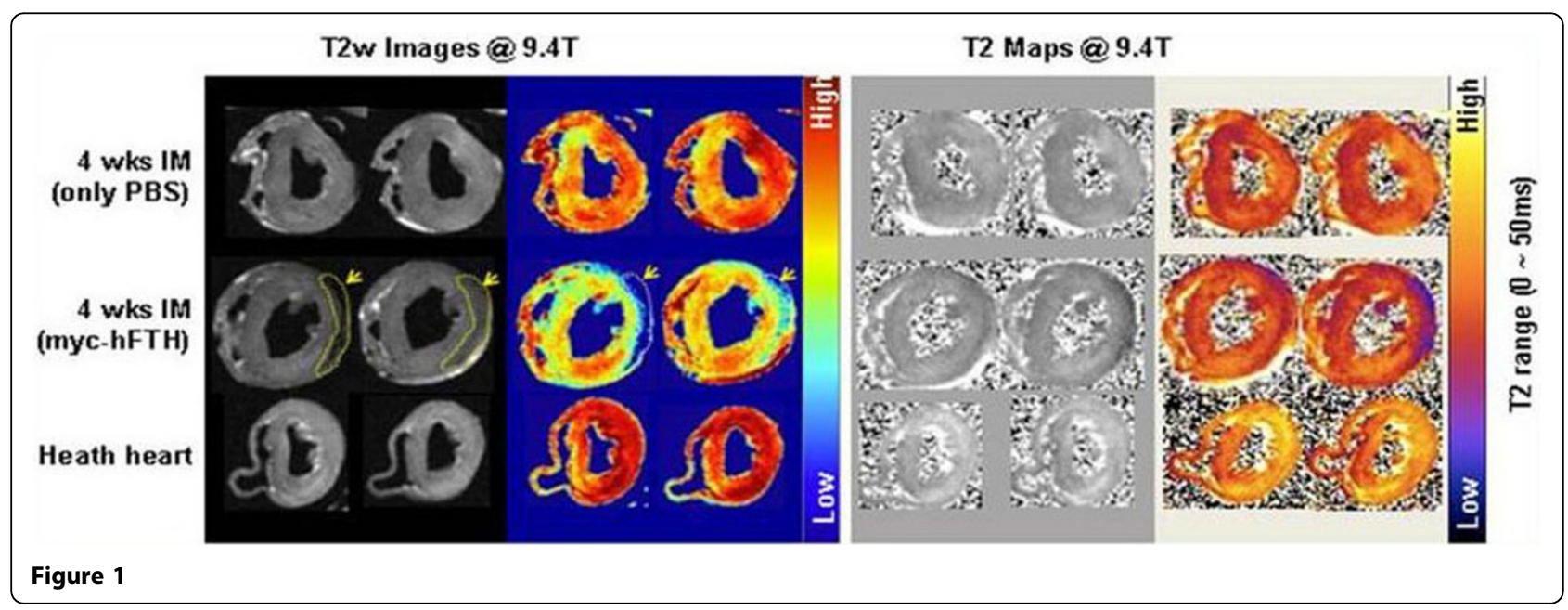

Radiology, Seoul National University Hospital, Seoul, Republic of Korea

C 2013 Park et al; licensee BioMed Central Ltd. This is an Open Access article distributed under the terms of the Creative Commons BHoWed Central Attribution License (http://creativecommons.org/licenses/by/2.0), which permits unrestricted use, distribution, and reproduction in any medium, provided the original work is properly cited. 


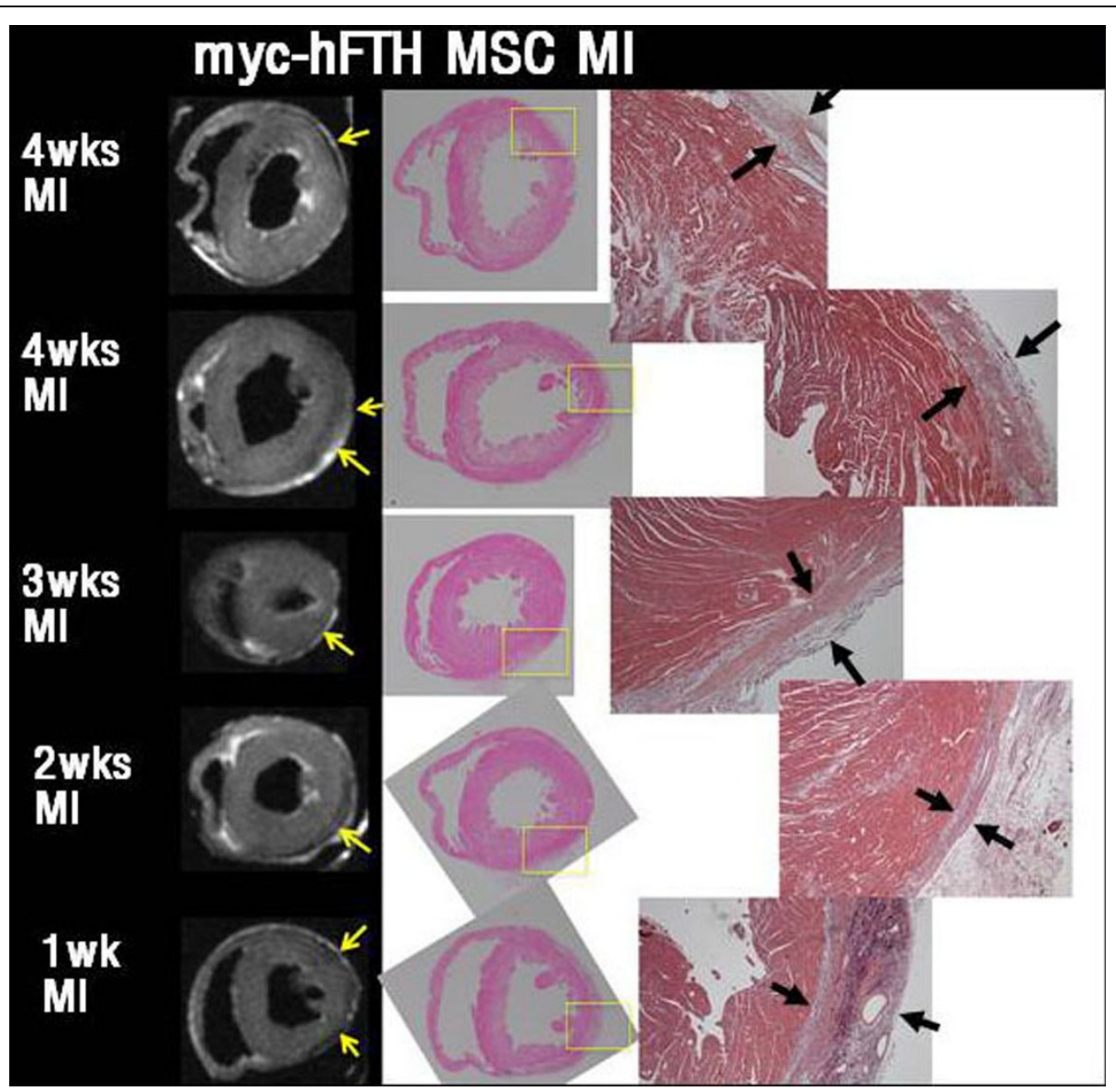

Figure 2

heart while simultaneously monitoring cardiac morphofunctional changes.

\section{Funding}

This study was supported by a grant of the Korean Health Technology R\&D Project, Ministry of Health \& Welfare, Republic of Korea (No.A100131) and partly by the National Research Foundation of Korea (NRF) grant funded by the Korean government (MEST) (2011-0000174, 20110005381).

Submit your next manuscript to BioMed Central and take full advantage of:

- Convenient online submission

- Thorough peer review

- No space constraints or color figure charges

- Immediate publication on acceptance

- Inclusion in PubMed, CAS, Scopus and Google Scholar

- Research which is freely available for redistribution 